\title{
Kecenderungan Mahasiswa Dalam Mengikuti Perkembangan Pasar Bebas ASEAN Di Fakultas Ekonomi Uika Bogor
}

\author{
Rachmatullaily, S.E., M.M ., Hannisa Rahmaniar Hasnin, S.Sos., M.A. \\ Denia Maulani, S.E., M.M.
}

Fakultas Ekonomi Univesitas Ibn Khaldun Bogor, Indonesia

\begin{abstract}
Abstrak
Masyarakat Ekonomi ASEAN (MEA) akan membentuk ASEAN menjadi pasar dan basis dari produksi tunggal yang dapat membuat ASEAN terlihat dinamis dan dapat bersaing dengan adanya mekanisme dan langkah-langkah dalam memperkuat pelaksanaan baru yang berinisiatif ekonomi; mempercepat perpaduan regional yang ada disektor-sektor prioritas; memberikan fasilitas terhadap gerakan bisnis, tenaga kerja memiliki bakat dan terampil; dapat memperkuat kelembagaan mekanisme di ASEAN. Untuk dapat bersaing dengan negara ASEAN lainnya, Indonesia harus dapat mempersiapkan generasi muda, salah satunya mahasiswa agar setelah lulus dapat memberikan kontribusi terbaik bagi negara. Berdasarkan tujuan tersebut perlu diketahui terlebih dulu seberapa jauh pemahaman mahasiswa mengenai topik MEA beserta dampaknya.
\end{abstract}

Kata Kunci: ASEAN, Pasar Bebas

\section{Pendahuluan}

\subsection{Latar Belakang Penelitian}

Masyarakat Ekonomi ASEAN (MEA)

adalah kerjasama perdagangan bebas

antar negara kawasan ASEAN, MEA

mulai berlaku akhir tahun 2015 dan

diberlakukan secara bertahap sehingga

kawasan negara ASEAN berada pada

satu wilayah perdagangan.

Pembentukan pasar tunggal yang

diistilahkan dengan Masyarakat

Ekonomi ASEAN (MEA) ini memungkinkan satu negara menjual barang dan jasa dengan mudah ke negara-negara lain di seluruh Asia Tenggara sehingga kompetisi akan semakin ketat.

Awal mula MEA berawal pada

KTT yang dilaksanakan di Kuala Lumpur pada tanggal 1997 dimana para pemimpin ASEAN akhirnya memutuskan untuk melakukan 
pengubahan ASEAN dengan menjadi suatu kawasan makmur, stabil dan sangat bersaing dalam perkembangan ekonomi yang berlaku adil dan dapat mengurangi kesenjangan dan kemiskinan sosial ekonomi (ASEAN Vision 2020).

Dilanjutkan pada KTT Bali yang terjadi pada bulan Oktober pada tahun 2003, para pemimpin ASEAN mengaluarkan pernyataan bahwa Masyarakat Ekonomi ASEAN atau MEA akan menjadi sebuah tujuan dari perilaku integrasi ekonomi regional di tahun 2020, ASEAN SECURITY COMMUNITY dan beberapa komunitas sosial Budaya ASEAN merupakan dua pilar yang tidak bisa terpisahkan dari komunitas Asea. Seluruh pihak diharapkan agar dapat bekerja sama secara kuat didalam membangun komunitas ASEAN di tahun 2020.

MEA akan mulai membentuk ASEAN menjadi pasar dan basis dari produksi tunggal yang dapat membuat ASEAN terlihat dinamis dan dapat bersaing dengan adanya mekanisme dan langkah-langkah dalam memperkuat pelaksanaan baru yang berinisiatif ekonomi; mempercepat perpaduan regional yang ada disektorsektor prioritas; memberikan fasilitas terhadap gerakan bisnis, tenaga kerja memiliki bakat dan terampil; dapat memperkuat kelembagaan mekanisme di ASEAN. Di saat yang sama, MEA akan dapat mengatasi kesenjangan pada pembangunan dan melakukan percepatan integrasi kepada negara Laos, Myanmar, Vietnam dan Kamboja lewat Initiative for ASEAN integration dan inisiatif dari regional yang lainnya.

Melihat keadaan yang terjadi sekarang ini Indonesia sebenarnya belum siap menghadapi MEA walaupun mempunyai peluang dan kekuatan tinggi. Laporan Kementerian Koordinator Perekonomian 
mengungkapkan bahwa Neraca mudi, ketika kesadaran akan

Perdagangan Indonesia sejak tahun

2005 setiap tahunnya mengalami defisit yang meningkat di negaranegara ASEAN. Indonesia dengan kekayaan alam yang besar ternyata ekspornya hanya didominasi oleh barang-barang berupa bahan baku alam (raw material), seperti batubara, minyak nabati, gas, dan minyak bumi. Indonesia masih kalah bersaing dengan negara-negara industri utama ASEAN seperti Singapura, Malaysia dan Thailand. Pengolahan bahan baku alam yang merupakan hasil Indonesia masih selalu dilakukan oleh negara lain, Indonesia belum mampu mengelola kekayaannya sendiri.

Kondisi seperti ini perlu adanya penyadaran bagi kaum-kaum muda sebegai generasi penerus bangsa ini. Generasi muda harus mempersiapkan dirinya ketika pasar bebas ASEAN sudah diberlakukan. Keberlanjutan negara ini ada di tangan kaum muda- pentingnya membenahi diri untuk menghadapi MEA bagi para generasi muda tidak ada, Indonesia nantinya akan terjual ke negara lain dan negara indonesai akan dikuasai oleh negara lain. Dukungan dari generasi muda untuk menghadapi MEA merupakan salah satu kekuatan Indonesia untuk dapat bertahan dalam persaingan pasar bebas. Generasi muda perlu membuat berbagai kegiatan diantaranya yaitu menciptakan usaha sendiri selagi mahasiswa, mensosialisasikan MEA dan mengajak kaum muda lain untuk meningkatkan daya wirausaha sehingga usaha-usaha baru akan muncul dan bisa mempertahankan perekonomian negara. Generasi muda merupakan salah satu tonggak keberhasilan tujuan Negara karena kaum mudalah pemegang keberlanjutan Negara salah satunya mahasiswa. Sehingga penulis mengambil penelitian ini adalah 
mahasiswa khusnya mahasiswa

Fakultas Ekonomi di UIKA Bogor

dengan judul "Kecenderungan

Mahasiswa Dalam Mengikuti

Perkembangan Pasar Bebas ASEAN

Di Fakultas Ekonomi Uika Bogor"

\subsection{Rumusan Masalah}

Berdasarkan indentifikasi dan

batasan masalah maka rumusan

masalah dalam penelitian ini adalah sebagai berikut:

1. Sejauh mana pemahaman mahasiswa terhadap Pasar Bebas ASEAN?

2. Bagaimana persepsi mahasiswa terhadap pasar bebas ASEAN ?

3. Apa mahasiswa paham dampak pasar bebas ASEAN terhadap perekonomian Negara?

\subsection{Tujuan Penelitian}

Berdasarkan perumusan masalah, maka tujuan penelitian adalah :

1. Mengetahui sejauh mana mahasiswa mengerti terhadap Pasar Bebas ASEAN
2. Mengetahui kecendrungan mahasiswa pasar bebas ASEAN

3. Mengatahui pemahaman mahasiswa terhadap dampak dari Pasar Bebas ASEAN

\subsection{Metode Penelitian}

\subsubsection{Pemilihan Informan Kunci}

Pada penelitian ini responden yang diambil adalah Mahasiswa Fakultas Ekonomi UIKA Bogor dengan total 1132 Mahasiswa yang terdiri dari 3 (tiga) program studi, yang ada di Fakultas Ekonomi Universitas Ibn Khaldun Bogor. Penelitian menggunakan kuisioner atau wawancara dalam pengumpulan datanya.

Ketepatan memilih dan menentukan jenis sumber data akan menentukan kekayaan data yang diperoleh. Salah satu sumber data menggunakan narasumber (informan) yang juga disebut disebut responden, yaitu orang yang memberikan "Respon" atau tanggapan terhadap apa yang diminta atau ditentukan oleh 
peneliti dan nara sumber sangat penting, bukan skedar memberi respon, melainkan juga sebagai pemilik informasi. Menurut Bagong Suyanto (2005:172) informan penelitian meliputi beberapa macam, yaitu:

1. Informan Kunci (Key Informan) merupakan mereka yang mengetahui dan memiliki berbagai informasi pokok yang diperlukan dalam penelitian.

2. Informan Utama merupakan mereka yang terlibat langsung dalam interaksi sosial yang diteliti.

3. Informan Tambahan merupakan mereka yang dapat memberikan informasi walaupun tidak langsung terlibat dalam interaksi sosial yang diteliti.

\subsubsection{Kriteria Informan Kunci}

Adapun Kriteria Informan

Kunci yang digunakan adalah

1. Representasi Klaster/Kelompok, yakni reprentasi yang berdasarkan kepada kelompok.

2. Representasi Kelas atau Tingkat, yakni informasi kunci merepresentasikan berdasarkan kepada tingkatan keilmuannya atau lama masa studi, yang dibagi dalam 2 kreteria :

a. Informan Studi awal adalah mahasiswa yang menempuh perkuliahan antara semester 1 s/d Semester 4.

b. Informan studi akhir adalah mahasiswa yang menempuh perkuliahan antara semester 5 s/d Semester 10.

Setiap kelompok dan tingkatan atau kelas harus terwakili dalam kriteria informan. Adapun kreteria Mahasiswa Fakultas Ekonomi

Universitas Ibn Khaldun Bogor sbb:

Tabel 1.1.

Kriteria Kelompok Mahasiswa Fakultas Ekonomi 


\begin{tabular}{|c|c|c|}
\hline $\begin{array}{c}\text { Program Studi } \\
\text { Manajemen }\end{array}$ & $\begin{array}{c}\text { Program Studi } \\
\text { Akuntansi }\end{array}$ & $\begin{array}{c}\text { Program Studi } \\
\text { Keuangan \& Perbankan }\end{array}$ \\
\hline Reguler & Reguler & Reguler \\
\hline Karyawan & Karyawan & Karyawan \\
\hline
\end{tabular}

Sumber: Data primer, diolah 2017

Tabel 1.2.

Kriteria berdasarkan tingkat

\begin{tabular}{|l|l|l|l|l|}
\hline \multicolumn{1}{|c|}{ Program Studi } & \multicolumn{4}{l}{ Jumlah Kelas } \\
\hline Manajemen Reguler & Kelas & Kelas & \multicolumn{1}{l|}{ Kelas } & Kelas \\
\hline Semester I & A & B & C & D \\
\hline Semester III & A & B & C & D \\
\hline Semester V & A & B & C & D \\
\hline Semester VII & A & B & C & D \\
\hline Manajemen Karyawan & Kelas & Kelas & Kelas & Kelas \\
\hline Semester I & A1 & A2 & B1 & B2 \\
\hline Semester III & A1 & & & \\
\hline Semester V & A1 & & B1 & \\
\hline Semester VII & A1 & & & \\
\hline Akuntansi Reguler & Kelas & Kelas & & \\
\hline Semester I & A & B & & \\
\hline Semester III & A & B & & \\
\hline Semester V & A & B & & \\
\hline Semester VII & A & B & & \\
\hline Akuntansi Karyawan & Kelas & Kelas & & \\
\hline Semester I & A & B & & \\
\hline Semester III & A & B & & \\
\hline Semester V & A & B & & \\
\hline Semester VII & A & B & & \\
\hline Keuangan dan Perbankan Reguler & Kelas & & & \\
\hline Semester I & A & & & \\
\hline Semester III & A & & & \\
\hline Semester V & A & & & \\
\hline Keuangan dan Perbankan Karyawan & Kelas & & & \\
\hline Semester I & A & & & \\
\hline Semester V & A & & & \\
\hline Jumlah Kelas & 21 & 13 & 6 & 5 \\
\hline Jumlah Keseluruhan Kelas & 45 & & \\
\hline & 2017 & \\
\hline
\end{tabular}

Sumber: Data primer, diolah 2017

Tabel 1.3.

Kategori Informan

\begin{tabular}{|l|l|l|l|l|}
\hline \multicolumn{1}{|c|}{ Program Studi } & \multicolumn{5}{c|}{ Jumlah Informan } \\
\hline Manajemen Reguler & A & B & C & D \\
\hline Semester I & 1 & & & \\
\hline Semester III & & 1 & & \\
\hline Semester V & & & 1 & \\
\hline Semester VII & & & & 1 \\
\hline Manajemen Karyawan & A & B & C & D \\
\hline Semester I & 1 & & & \\
\hline Semester III & & 1 & & \\
\hline Semester V & & & 1 & \\
\hline
\end{tabular}




\begin{tabular}{|l|l|l|l|l|}
\hline Semester VII & & & & 1 \\
\hline Akuntansi Reguler & A & B & C & D \\
\hline Semester I & 1 & & & \\
\hline Semester II & & 1 & & \\
\hline Semester V & & & & 1 \\
\hline Semester VII & A & B & C & D \\
\hline Akuntansi Karyawan & 1 & & & \\
\hline Semester I & & 1 & & \\
\hline Semester III & & & 1 & \\
\hline Semester V & & & & 1 \\
\hline Semester VII & A & B & C & D \\
\hline Keuangan dan Perbankan Reguler & 1 & & & \\
\hline Semester I & 1 & & & \\
\hline Semester III & & & 1 & \\
\hline Semester V & A & B & C & D \\
\hline Keuangan dan Perbankan Karyawan & 1 & & & \\
\hline Semester I & & & 1 & \\
\hline Semester V & 7 & 4 & 6 & 4 \\
\hline Jumlah & 21 & & & \\
\hline Jumlah Keseluruhan & & \\
\hline
\end{tabular}

Sumber: Data primer, diolah 2017

Dari data diatas maka sebagai sampel yang diambil sebanyak 21 Mahasiswa yang mewakili setiap semester/kelas, dengan ketegori sebagai berikut:

1. A dab B merupakan mahasiswa studi awal yakni antara semester $1 \mathrm{~s} / \mathrm{d} 4$

2. $\mathrm{C}$ dan $\mathrm{D}$ mefrupakan mahasiswa studi akhir yakni antara semester $5 \mathrm{~s} / \mathrm{d} 8$

\section{Tinjauan Pustaka}

\subsection{Pasar Bebas}

Pasar bebas adalah suatu pasar yang dimana para penjual dan para pembeli mempunyai kebebasan penuh dalam memutuskan masalah perdagangan dan juga bisnisnya. Dapat disebut juga, di dalam sistem ekonomi pasar bebas, para penjual maupun para pembeli benar-benar memiliki kebebasan yang penuh dalam menjalankan

kegiatan-kegiatan perdagangan mereka menurut Sadono Sukirno (2009)

Pengertian pasar bebas menurut beberapa ahli dibawah ini definisi pasar bebas menurut pendapat beberapa para ahli:

1. Menurut David Ricardo, perdagangan bebas merupakan $\quad$ sistem perdagangan luar negeri 
dimana setiap negara

melakukan perdagangan

tanpa ada halangan negara.

2. Menurut Adam Smith, pasar bebas sebagai suatu wadah untuk menampung yang dihasilkan oleh setiap individu yang berpangkal pada paham kebebasan yang diberikan kepada pelaku - pelaku ekonomi untuk menjalankan kegiatan ekonomi sesuai dengan keinginan mereka tanpa ada campur tangan pemerintah.

\subsection{Ciri-Ciri Sistem Ekonomi Pasar}

\section{Bebas}

Menurut Boediono (2000) Ciri dari sistem ekonomi pasar bebas yaitu:

1. Alat dan juga sumber produksi dapat dimiliki serta diatur oleh individu, masyarakat, ataupun perusahaan.

2. Adanya pembagian kelas didalam masyarakat, ialah kelas pekerja atau kelas buruh dan kelas pemilik modal.

3. Terjadinya persaingan antara para pengusaha untuk mendapatkan keuntungan yang optimal atau yang sebesarbesarnya (profit motive).

4. Lalu pemerintah tidak melakukan campur tangan dalam pasar. Campur tangan dari negara dibatasi hanya pada hal-hal yang tidak dapat diusahakan oleh swasta, tapi menjadi syarat terselenggaranya pasar bebas, seperti misalnya keamanan negara.

\subsection{Kelebihan Dan Kelemahan}

\section{Sistem Ekonomi Pasar Bebas}

Kelebihan sistem ekonomi pasar bebas, diantaranya seperti:

1. Setiap individu bebas mempunyai kekayaan serta sumber daya produksi. 
2. Inisiatif dan juga kreatifitas masyarakat bisa dikembangkan.

3. Terjadinya persaingan diantara produsen untuk menghasilkan produk yang berkualitas.

4. Efisiensi dan efektivitas yang tinggi sebab tindakannya selalu didasarkan pada prinsip ekonomi.

Menurut Odaro, Michael P.; Smith, Stephen C. (2009) Kelemahan sistem ekonomi pasar bebas, diantaranya seperti:

1. Adanya eksploitasi terhadap masyarakat yang ekonomi lemah oleh pihak ekonominya kuat.

2. Dapat menimbulkan terjadinya monopoli sehingga dapat merugikan masyarakat.

3. Dapat munculnya kesenjangan ekonomi diantara golongan ekonomi kuat dengan golongan ekonomi yang lemah.
4. Dapat dengan mudah menimbulkan perekonomian yang tidak stabil.

\section{4 .Manfaat Diberlakukannya}

\section{Masyarakat Ekonomi ASEAN}

Pentingnya

Masyarakat

Ekonomi ASEAN tidak terlepas dari dampak positif dan manfaat dari diberlakukannya perdagangan bebas diwilayah regional Asia Tenggara tersebut. Mungkin saat ini dampak positifnya belum begitu terasa karena MEA baru saja diberlakukan yaitu pada tahun 2015, namun diharapkan manfaat besarnya akan terasa pada tahun-tahun selanjutnya. Dan dibawah ini adalah beberapa dampak positif atau manfaat dari Masyarakat Ekonomi ASEAN itu sendiri menurut Arifin (2008) adalah;

1. Masyarakat Ekonomi ASEAN akan mendorong arus investasi dari luar masuk ke dalam negeri yang akan menciptakan multiplier effect dalam berbagai 
sektor khususnya dalam bidang pembangunan ekonomi.

2. Kondisi pasar yang satu (pasar tunggal) membuat kemudahan dalam hal pembentukan joint venture (kerjasama) antara perusahaan-perusahaan diwilayah ASEAN sehingga akses terhadap bahan produksi semakin mudah.

3. Pasar Asia Tenggara merupakan pasar besar yang begitu potensial dan juga menjanjikan dengan luas wilayah sekitar 4,5 juta kilometer persegi dan jumlah penduduk yang mencapai 600 juta jiwa.

4. MEA memberikan peluang kepada negara-negara anggota
ASEAN dalam hal meningkatkan kecepatan perpindahan sumber daya manusia dan modal yang merupakan dua faktor produksi yang sangat penting.

5. Khusus untuk bidang teknologi, diberlakukannya Masyarakat Ekonomi ASEAN ini menciptakan adanya transfer teknologi dari negara-negara maju ke negara-negara berkembang yang ada diwilayah Asia Tenggara.

\section{Temuan Hasil Penelitian}

Untuk mendapatkan gambaran lebih jelas, dapat dilihat berdasarkan jawaban pertanyaan berikut.

Tabel 3.1. Sejauh mana pemahaman anda tentang Pasar Bebas (MEA-Masyarakat Ekonomi Asean)?

\begin{tabular}{|c|c|c|c|}
\hline No. & Pemahaman mengenai MEA & Jumlah (orang) & Prosentase \\
\hline 1 & Paham & 10 & $47,6 \%$ \\
\hline 2 & Tidak Paham & 11 & $52,4 \%$ \\
\hline & Total & 21 & 100,00 \\
\hline
\end{tabular}

Sumber: Data primer, diolah 2017 
Pada tabel 3.1. menjelaskan bahwa mayoritas responden tidak memahami konsep pasar bebas ASEAN atau MEA sebanyak 11 orang $(52,4 \%)$. Responden mengaku bahwa mereka hanya pernah dengar atau pernah disampaikan dalam kelas namun belum begitu memahami secara mendalam. Sebanyak 10 orang responden (47\%) yang dapat menjawab mengenai MEA. Hal ini tergambar dari hasil wawancara individu salah seorang responden "MEA sendiri itu pada dasarnya adalah sebuah penjanjian Negara Negara ASEAN dan merupakan pasar bebas, termasuk Investasi.”.

Tabel 3.2. Bagaimana pendapat anda atas masuknya Pasar Tenaga Kerja Asing ke Indonesia saat ini? Apakah anda setuju? Apa yang menjadi alasan anda?

\begin{tabular}{|c|c|c|c|}
\hline No. & $\begin{array}{c}\text { Masuknya pasar tenaga kerja } \\
\text { asing }\end{array}$ & Jumlah (orang) & Prosentase \\
\hline 1 & Setuju & 4 & $19 \%$ \\
\hline 2 & Tidak setuju & 17 & $81 \%$ \\
\hline & Total & 21 & $100 \%$ \\
\hline
\end{tabular}

Sumber: Data primer, diolah 2017

Berdasarkan tabel 3.2. dapat

dijelaskan bahwa mayoritas responden tidak menyetujui dengan masuknya tenaga kerja asing ke Indonesia sebanyak 17 orang (81\%) dengan alasan yang bervariasi yaitu karena masih banyaknya pengangguran dalam negeri hingga merasa belum dapat bersaing dengan pekerja asing. Dapat digambarkan dalam hasil wawancara dengan responden "Kurang setuju, kalau tenaga kerja asing masuk karena lebih berkualitas maka akan banyak pengangguran karena gak mampu bersaing".

Sedangkan hanya ada 4 responden (19\%) yang menyatakan setuju masuknya tenaga kerja asing ke Indonesia dengan alasan bahwa akan menambah wawasan bagi pekerja 
Indonesia. Selain itu dengan masuknya

tenaga kerja asing diharapkan dapat

mendorong tenaga kerja Indonesia agar

lebih mampu bersaing. Seperti kutipan berikut "Tenaga kerja asing itu sebagai acuan kita untk bersaing walaupun kita belum siap".

Tabel 3.3. Bagaimana pendapat anda atas masuknya Investasi Negara-Negara Asia Tenggara Ke Indonesia Saat ini?

\begin{tabular}{|c|c|c|c|}
\hline No. & $\begin{array}{c}\text { Masuknya investasi negara } \\
\text { ASEAN }\end{array}$ & Jumlah (orang) & Prosentase \\
\hline 1 & Setuju & 14 & $66,7 \%$ \\
\hline 2 & Tidak setuju & 7 & $33,3 \%$ \\
\hline & Total & 21 & $100 \%$ \\
\hline
\end{tabular}

Sumber: Data primer, diolah 2017

Tabel

3.3. dapat

solusi bagi pemerintah dalam bidang

menggambarkan bahwa walaupun

mereka tidak setuju dengan masuknya

tenaga kerja asing masuk, namun

untuk investasi asing yang masuk ke

Indonesia disetujui oleh mayoritas

responden sebanyak 14 orang $(66,7 \%)$.

Hal ini dianggap positif karena dapat

mendorong

perkembangan

pembangunan dan ekonomi Indonesia,

tetapi responden mengatakan untuk

tetap menyertakan investor lokal dalam

pembangunan. Selain itu responden

menilai dengan adanya investasi asing

masuk ke Indonesia dapat memberikan yang terbatas dananya, seperti berikut

"Setuju , Indonesia memiliki

keterbatasan di bidang investasi,

dengan masuknya Investasi akan

mempercepat misi pemerintah dalam

membangun infrastuktur.”. Responden

yang tidak setuju masuknya investasi

asing sebanyak 7 orang $(33,3 \%)$

menilai bahwa investor lokal dan

pemerintah yang sebaiknya memegang

pembangunan dan perekonomian,

karena dikhawatirkan adanya dominasi

perusahaan asing yang dapat

merugikan negara Indonesia 
Tabel 3.4. Bagaimana pendapat anda mengenai pembangunan yang ada saat ini di Indonesia?

\begin{tabular}{|c|c|c|c|}
\hline No. & Pembangunan di Indonesia & Jumlah (orang) & Prosentase \\
\hline 1 & Pembangunan berjalan & 14 & $66,7 \%$ \\
\hline 2 & Pembangunan tidak berjalan & 7 & $33,3 \%$ \\
\hline & Total & 21 & $100 \%$ \\
\hline
\end{tabular}

Sumber: Data primer, diolah 2017
Berdasarkan tabel
3.4 .
Responden yang berpendapat

mayoritas responden menjelaskan

bahwa pembangunan sedang terjadi di

Indonesia secara pesat dan dengan

hasil yang baik. Terdapat 14 responden

$(66, \%)$ yang menyatakan bahwa

pembangunan di Indonesia sangat baik

dan dirasakan di seluruh Indonesia,

sehingga tercipta perbaikan

infrastruktur, peningkatan ekonomi

dan kesejahteraan. Namun yang harus

diperhatikan dalam pembangunan ini

antara lain adalah proses pembangunan

harus disesuaikan dengan tata kota

sehingga lingkungan tidak terkena efek

sampingnya, serta seimbangnya

pembangunan di kota dan desa. bahwa pembangunan di Indonesia tidak berjalan dengan baik sebanyak 7 orang (33,3\%). Mereka menjelaskan bahwa pembangunan yang terjadi tidak merata, hanya dirasakan oleh perkotaan saja, sedangkan desa atau daerah terpencil belum merasakan efek pembangunan. Seperti yang disampaikan responden "Pembangunan dipelosok tidak dilakukan dan ketimpangan itu masih ada ketika pak Jokowi melakukan pembangunan jauh dari desa jadi belum memilki mamfaat bagi masyarakat".

Tabel 3.5. Menurut anda apakah Indonesia saat ini siap untuk bekompetisi /berpartisipasi dalam Masyarakat Ekonomi Asean?

\begin{tabular}{|c|c|c|c|}
\hline No. & $\begin{array}{c}\text { Indonesia berkompetisi } \\
\text { /berpartisipasi dalam MEA }\end{array}$ & Jumlah (orang) & Prosentase \\
\hline 1 & Siap & 9 & $42.9 \%$ \\
\hline 2 & Tidak siap & 12 & $57,1 \%$ \\
\hline & Total & 21 & $100 \%$ \\
\hline
\end{tabular}

Sumber: Data primer, diolah 2017 
Berdasarkan tabel 3.5. dapat dijelaskan bahwa Indonesia saat ini masih belum siap untuk berkompetisi atau berparisipasi dalam MEA, hal ini ditunjukkan dengan 12 responden $(57,1 \%)$ yang menyatakan tidak siap. Responden mengemukakan Indonesia masih belum siap dari sisi sumber daya manusia seperti kemampuan yang dimiliki serta pendidikan yang belum siap bersaing dengan orang dari negara tetangga, perekonomian yang masih belum baik, UKM yang kurang didukung oleh pemerintah, dan lainnya.

Menurut 9 orang responden $(42,9 \%)$ menjelaskan bahwa Indonesia siap berkompetisi dan berpartisipasi dalam MEA karena memiliki sumberdaya alam yang berlimpah. Sebagian besar menyatakan bahwa Indonesia harus siap untuk ikut berkompetisi atau berpartisipasi dalam MEA agar Indonesia dapat maju. Selanjutnya semua pihak harus melakukan percepatan agar dapat siap bersaing dan berpartisipasi seperti pemerintah menyiapkan peraturan yang dapat mendorong usaha atau masyarakat dalam negeri dapat bersaing dan masyarakat secara individu harus mempersiapkan kemampuan diri.

Tabel 3.6. Saat ini kita mau tidak mau harus terlibat dalam MEA, apakah yang menjadi prioritas oleh Indonesia? Apakah Investasi asing, pasar tenaga kerja, atau memperkuat ekonomi regional?

\begin{tabular}{|c|c|c|c|}
\hline No. & Prioritas daya saing Indonesia & Jumlah (orang) & Prosentase \\
\hline 1 & Investasi Asing & 5 & $23,8 \%$ \\
\hline 2 & Pasar tenaga kerja & 11 & $52,4 \%$ \\
\hline 3 & Memperkuat ekonomi regional & 5 & $23,8 \%$ \\
\hline & Total & 21 & $100 \%$ \\
\hline
\end{tabular}
Sumber: Data primer, diolah 2017

Berdasarkan tabel 3.6. pasar terlibat dalam MEA, peringkat tenaga kerja merupakan hal yang harus investasi asing dan memperkuat menjadi prioritas jika Indonesia mau ekonomi regional menjadi pendukung 
keberhasilan Indonesia dalam Indonesia memperkuat investasi dari menghadapi persaingan. Sebanyak 11 asing.”.

orang responden $(52,4 \%)$ menyatakan

Responden yang berpendapat bahwa pasar tenaga kerja merupakan hal yang penting selain karena masih banyaknya pengangguran yang ada, banyak potensi sumber daya manusia Indonesia yang perlu untuk didorong dan dimaksimalkan pemanfaatannya dalam memasuki era persaingan MEA. Hal ini dapat dilihat dalam hasil wawancara "Prioritas Indonesia adalah pendidikan yang berkualitas agar pendudk Indonesia bisa bersaing di luar negeri dan menciptakan (secara ekonomi), pondasi dan pengusaha baru agar bisa menciptakan ekonomi harus kuat dulu, jangan lapangan kerja baru sehingga tenaga seperti sekarang ini ekonomi kita kerja tak perlu ke luar negeri, sedang terpuruk.".

Tabel 3.7. Bagaimana peran anda sebagai mahasiswa sekaligus sebagai mahasiswa dalam menghadapi MEA?

\begin{tabular}{|c|c|c|c|}
\hline No. & Peran mahasiswa & Jumlah (orang) & Prosentase \\
\hline 1 & Peran penting & 19 & $90,5 \%$ \\
\hline 2 & Peran belum penting & 2 & $9,5 \%$ \\
\hline & Total & 21 & $100 \%$ \\
\hline
\end{tabular}
Sumber: Data primer, diolah 2017

Berdasarkan tabel 3.7. hanya untuk menghadapi MEA, karena ada 2 orang responden $(9,5 \%)$ yang beranggapan masih dalam wilayah menyatakan bahwa mahasiswa tidak kampus dan belum terjun ke memiliki peran dalam masyarakat masyarakat sehingga belum dapat 
melakukan sesuatu dan belum agent of social dimana mahasiswa ada memikirkan perannya dalam di tengah-tengah dimana bisa masyarakat untuk menghadapi MEA. menyambung lidah masyarakat, ketika Mayoritas responden sebanyak 19 ada isu apapun dari masyarakat dapat orang $(90,5 \%)$ berpendapat mereka dilihat melalui banyak link atau canal memiliki peran sangat besar dan seperti sosial media, dan ketika penting dalam menghadapi MEA, aspirasi kita tak di dengar oleh seperti hasil wawancara berikut pemerintah maka kita bisa "Mahasiswa mempunyai 3 peran yaitu menggunakan media yang umum.”. agent of change, agent of control dan

Tabel 3.8. Anda sebagai mahasiswa, standar kualitas apa yang anda harus miliki untuk mampu bersaing didalam MEA? Apakah bahasa, informasi dan teknologi, keahlian spesifik, komunikasi interpersonal, atau yang lainnya?

\begin{tabular}{|c|c|c|c|}
\hline No. & Standar kualitas individu & Jumlah (orang) & Prosentase \\
\hline 1 & Bahasa & 11 & $52,4 \%$ \\
\hline 2 & Informasi dan teknologi & 3 & 14,3 \\
\hline 3 & Keahlian spesifik & 7 & $33,3 \%$ \\
\hline 4 & Komunikasi interpersonal & 0 & $0 \%$ \\
\hline 5 & Lainnya & 0 & $0 \%$ \\
\hline & Total & 21 & $100 \%$ \\
\hline
\end{tabular}

Sumber: Data primer, diolah 2017

Bahasa merupakan standar

kualitas utama yang harus dimiliki agar dapat mampu bersaing berdasarkan tabel 3.8. dari pendapat 11 orang responden $(52,4 \%)$. Penguasaan bahasa asing diniai penting untuk dapat menjalin komunikasi yang lancar ketika berhadapan dengan orang dari negara lain, juga ketika kita pergi keluar negeri. Standar kualitas teratas kedua yang dinilai penting adalah keahlian spesifik sebanyak 7 orang responden (33,3\%), seperti hasil wawancara berikut "Skill, bagaimana kita mau bersaing dengan negara asing ketika kita tidak punya skill, bahasa, teknologi. Kita tidak boleh ketinggalan perkembangan dari negara lain.”. 
Peringkat teratas ketiga untuk

standar kualitas yang harus dimiliki adalah informasi dan teknologi yang dipilih oleh 3 orang responden (14,3\%). Mereka berpendapat "Informasi, ilmu lebih banyak mengenal pekrjaan kita, dan persiapan kita harus matang."

\section{Penutup}

\subsection{Kesimpulan}

1. Pemahaman mahasiswa yang menjadi informan dalam penelitian ini mengenai pasar bebas ASEAN masih kurang. Hal ini ditunjukkan pada respon, sikap, dan jawabanjawaban yang diberikan bersifat umum dan tidak mendalam. Bahkan ada informan yang tidak dapat memberikan jawaban karena ketidak tahuan, atau responden memberikan jawaban namun tidak sesuai dengan pertanyaan yang diberikan. Seperti dalam wawancara pertanyaan 1 dimana mayoritas responden tidak memahami konsep pasar bebas ASEAN atau MEA sebanyak 11 orang $(52,4 \%)$. Responden mengaku bahwa mereka hanya pernah dengar atau pernah disampaikan dalam kelas namun belum begitu memahami secara mendalam. Sebanyak 10 orang responden (47\%) yang dapat menjawab mengenai MEA.

Pemahaman mahasiswa yang diwakilkan oleh informan masih kurang mendalam, hal ini dikarenakan informasi mengenai ASEAN, pasar bebas ASEAN atau MEA hanya berdasarkan pengajaran dosen di kelas. Sedangkan beberapa informan lainnya mendapatkan informasi dari hasil diskusi dengan teman kuliahnya yang lain. Buku, berita, situs internet dan sumber lainnya yang 
terkait dengan ASEAN belum

menjadi bahan rujukan lebih

lanjut dalam mendapatkan

informasi atau pengetahuan

agar menambah wawasan

informan.

2. Persepsi mahasiswa yang diwakilkan oleh para informan, sebagian besar beranggapan bahwa dengan berlakunya pasar bebas ASEAN atau MEA akan membuat persaingan tenaga kerja akan semakin ketat karena masuknya tenaga kerja asing dari negara ASEAN lainnya, sehingga diperlukan adanya regulasi yang jelas dari pemerintah agar tenaga kerja lokal tidak terpinggirkan. Selain itu investasi dari negaranegara ASEAN lainnya yang lebih mudah masuk Indonesia akan berdampak positif bagi pembangungan dan ekonomi Indonesia, namun para informan sepakat bahwa investor lokal perlu diutamakan sebelum masuknya investor asing.

Para informan lebih dari setengahnya menyatakan bahwa Indonesia belum siap ikut berkompetisi atau berparisipasi dalam MEA, hal ini ditunjukkan dengan 12 responden $\quad(57,1 \%) \quad$ yang menyatakan tidak siap. Sedangkan 9 orang responden $(42,9 \%)$ menjelaskan bahwa Indonesia siap berkompetisi dan berpartisipasi dalam MEA. Sebagian besar menyatakan bahwa Indonesia harus siap untuk ikut berkompetisi atau berpartisipasi dalam MEA agar Indonesia dapat maju.

Agar dapat ikut berpartisipasi dan berkompetisi dalam pasar bebas ASEAN, bahasa merupakan standar kualitas 
utama yang harus dimiliki. Hal ini merupakan dari pendapat 11

orang responden $(52,4 \%)$

karena penguasaan bahasa asing dinilai penting untuk dapat menjalin komunikasi yang lancar ketika berhadapan dengan orang dari negara lain.Standar kualitas teratas kedua yang dinilai penting adalah keahlian spesifik sebanyak 7 orang responden (33,3\%). Peringkat teratas ketiga untuk standar kualitas yang harus dimiliki adalah informasi dan teknologi yang dipilih oleh 3 orang responden $(14,3 \%)$.

3. Sebagian besar informan memahami bahwa pasar bebas ASEAN memiliki dampak pada perekonomian negara Indonesia, seperti masuknya investasi dari negara-negara ASEAN berdampak baik yaitu mendorong pembangunan serta ekonomi Indonesia. Namun selain itu juga memiliki dampak buruk dengan semakin mudahnya investor asing masuk, dikhawatirkan akan mendominasi perekonomian dan kepemilikan perusahaanperusahaan di Indonesia sehingga investor lokal dapat terpinggirkan. Ada juga informan yang tidak memahami dampak dari adanya pasar bebas ASEAN, setelah dilakukan wawancara grup dan mendengar jawaban informan lainnya baru ada sedikit pemahaman mengenai dampaknya.

\subsection{Saran}

1. Untuk memberikan pemahaman yang baik mengenai ASEAN pada umumnya dan pasar bebas ASEAN pada khususnya perlu 
peran semua pihak baik dosen

maupun mahasiswa. Dosen

yang menyampaikan topik yang

terkait pasar bebas ASEAN

perlu memutakhirkan bahan

ajar dan disertai dengan contoh

yang aplikatif sehingga

mahasiswa dapat memahami

dan dapat menjelaskan kembali

dengan baik mengenai pasar

bebas ASEAN. Adapun

mahasiswa juga memiliki peran

penting dalam pengembangan

wawasan dirinya melalui

pengayaan literatur, mengikuti

berita dan informasi mengenai

pasar bebas ASEAN dan

melakukan diskusi lebih lanjut.

2. Agar mahasiswa siap dalam menghadapi pasar bebas ASEAN, dapat diselenggarakan pelatihan untuk meningkatkan kemampuan mahasiswa dalam bidang keilmuan terkait atau menyelenggarakan seminar untuk menambah wawasan mahasiswa.

3. Agar mahasiswa dapat memahami dengan baik dampak pasar bebas ASEAN bagi perekonomian Indonesia, dosen dapat memberikan studi kasus yang dapat dipelajari bersama dengan mahasiswa. Selain itu mahasiswa dapat melakukan riset penelitian skripsi yang terkait dengan pasar bebas ASEAN agar lebih memahami dampaknya secara lebih baik dan jelas.

\section{DAFTAR PUSTAKA}

Arifin Samsul, 2008, Masyarakat Ekonomi ASEAN 2015, Memperkuat Sinergi ASEAN Ditengah Kompetisi Global, Jakarta: PT. Elex Media Komputindo

Bagong, Suyanto. 2005. Metode Penelitian Sosial. Jakarta: Kencana Prenada Media Group

Boediono. 2000, Ekonomi Moneter, edisi 3, BPFE: Yogyakarta.

Sukirno Sadono, 2009. Mikro Ekonomi Teori Pengantar", Edisi Ketiga, Jakarta: Rajawali Pers, 
Jurnal IImiah Inovator, Edisi September 2017

Odaro, Michael P.; Smith, Stephen

C. (2009).Economic Development (10th ed.). Addison Wesley. p. 839 